\title{
The determination of the standard Gibbs energies of ion transfer between water and heavy water by using the three-phase electrode approach
}

\author{
Rubin Gulaboski ${ }^{\text {a }}$, Karolina Caban ${ }^{\text {b }}$, Zbigniew Stojek ${ }^{\mathrm{b}}$, Fritz Scholz ${ }^{\mathrm{a}, *}$ \\ ${ }^{a}$ Institut für Chemie und Biochemie, Ernst-Moritz-Arndt-Universität, Soldmannstrasse23, D-17489 Greifswald, Germany \\ ${ }^{\mathrm{b}}$ Department of Chemistry, University of Warsaw, Pasteura 1, PL-02-093 Warszawa, Poland
}

Received 19 November 2003; received in revised form 28 November 2003; accepted 1 December 2003

Published online: 19 December 2003

\begin{abstract}
For the first time, the standard Gibbs energies of transfer of anions and cations across the nitrobenzene|heavy water interface are reported as measured by an electrochemical technique. The data have been obtained with the help of three-phase electrodes consisting of a nitrobenzene droplet that contains an electroactive compound (either decamethylferrocene to transfer anions or iron(III) tetraphenyl porphyrin chloride to transfer cations), a graphite electrode on the surface of which the droplet is attached, and a solution of the salts with the transferable ions in heavy water. The difference between these Gibbs energies of transfer and those of transfer between light water and nitrobenzene allows calculating the Gibbs energies of transfer between light water and heavy water. The latter vary in the interval from -0.50 to $+0.50 \mathrm{~kJ} / \mathrm{mol}$ with confidence intervals ranging from \pm 0.054 to $\pm 0.117 \mathrm{~kJ} / \mathrm{mol}$.
\end{abstract}

(C) 2003 Elsevier B.V. All rights reserved.

Keywords: Standard Gibbs energy of ion transfer; Three-phase electrode; Heavy water; Decamethylferrocene; Iron(III) tetraphenyl porphyrine

\section{Introduction}

The effect of isotope exchange upon the kinetics [1-3] of chemical reactions has been used since long to get a deeper understanding of chemical and biological systems. However, there are also interesting effects of isotope exchange upon the thermodynamics of molecular interactions, e.g., solvation. Comparative studies of the solubilities of various compounds in $\mathrm{H}_{2} \mathrm{O}$ and $\mathrm{D}_{2} \mathrm{O}$ as well as studies of solubilities of deuterated or otherwise isotope substituted compounds in water and other solvents have been published [4]. To the best of our knowledge we do not know any publication of data on the ion transfer between heavy water and organic solvents that were measured with electrochemical tech-

\footnotetext{
${ }^{*}$ Corresponding author. Tel.: +49-3834-864-450; fax: +49-3834-864451.

E-mail address: fscholz@uni-greifswald.de (F. Scholz).
}

niques, although, according to a private communication [5], such attempts have been made with the help of the four-electrode technique [6].

The recently developed technique to determine Gibbs energies of ion transfer using three-phase electrodes with organic solvent droplets immobilized on electrode surfaces proved to be useful for various solvent systems, e.g., water/nitrobenzene, water/dichloroethane, water/2nitrophenyloctyl ether, water $/ n$-octanol, water/menthol [7-16]. Since that technique provides rather low standard deviation data and offers an accuracy of the formal-potential measurement of $1 \mathrm{mV}$, we attempted to measure the small differences in Gibbs energies of ion transfer at the two interfaces $\mathrm{H}_{2} \mathrm{O} \mid$ nitrobenzene and $\mathrm{D}_{2} \mathrm{O} \mid$ nitrobenzene. We could prove that these small differences can be determined, and more importantly, the data have been determined much below the solubility limits of the salts. This minimizes activity effects and allows a better comparison between the ions. 


\section{Experimental}

All the chemicals used were of analytical grade purchased from Sigma-Aldrich, Germany, while suprofen, warfarine, benzoic acid and picric acid were products of Fluka (Buch, Switzerland). Heavy water with 99.9\% deuterium was obtained from Groupe Ceci, C.E. Saclay, France. All the salts used were dried at a temperature of $200{ }^{\circ} \mathrm{C}$. One $\mathrm{mol} / \mathrm{l} \mathrm{NaOD}$ solution was prepared by dissolving of metallic sodium in heavy water. A droplet with a volume of $1 \mu \mathrm{l}$ of $0.1 \mathrm{~mol} / \mathrm{l}$ solution of decamethylferrocene (dmfc) or $\mathrm{Fe}(\mathrm{III})$ tetraphenyl porphyrine (Fe(III)TPP) dissolved in nitrobenzene (NB) was attached to the surface of the paraffin impregnated graphite electrode (i.e., the working electrode). The modified working electrode was subsequently immersed in light water or heavy water solutions of different salts containing the transferable anions (when oxidation of $\mathrm{dmfc}$ was performed) or the transferable cations (when reduction of Fe(III)TPP was performed). For the voltammetric experiments a specially designed cell was used that needs only $100-200 \mu$ solution [12]. A tube with an inner diameter of $1 \mathrm{~mm}$, filled with saturated solution of $\mathrm{KCl}$ (dissolved in light water or heavy water, correspondingly) in Agar-Agar served as a salt bridge between the reference electrode $(\mathrm{Ag} / \mathrm{AgCl} /$ saturated $\mathrm{KCl})$ and the working cell, while a $\mathrm{Pt}$ wire melted into the bottom of the cell served as a counter electrode. Squarewave (SW) voltammetry [17] was used for precise and reproducible measuring the peak potentials which correlate well with the corresponding formal potentials. All measurements have been performed at $24 \pm 1{ }^{\circ} \mathrm{C}$ room temperature. From measurements with thermostated cells we know that there was no measurable difference in peak potentials between 22 and $28^{\circ} \mathrm{C}$, so that it is reasonable to use the room temperature measurements for the calculation of the standard values. ${ }^{1}$ Typical instrumental parameters were: SW frequency $f=10 \mathrm{~Hz}$, SW amplitude $E_{\mathrm{sw}}=50 \mathrm{mV}$, and scan increment $\mathrm{d} E=1$ $\mathrm{mV}$. At least 10 measurements were made for each single concentration of each transferable ion in both light water and heavy water, and the average value of the peak potentials was used for calculations. All data were statistically analyzed. The confidence intervals of the $\Delta G_{\alpha_{\mathrm{i}}}^{\beta^{\theta}}$ values vary from \pm 0.054 to $\pm 0.117 \mathrm{~kJ} \mathrm{~mol}^{-1}$ (for $P=0.9$ ). The standard potentials of $\mathrm{dmfc}$ and $\mathrm{Fe}(\mathrm{III}) \mathrm{TPP}$ in NB were the same as reported previously $[11,16]$.

\footnotetext{
${ }^{1}$ Taking into account the temperature dependence of dielectric constants of water and nitrobenzene it follows from Born theory that a variation of temperature by $1 \mathrm{~K}$ leads around $25^{\circ} \mathrm{C}$ to a shift of peak potentials from 0.1 to $0.3 \mathrm{mV}$ for the studied ions. This is below that what can be detected in our measurements.
}

\section{Results and discussion}

When ions i are transferred once from regular water to nitrobenzene and again from heavy water to nitrobenzene, then the difference between the calculated standard Gibbs energies of transfer of $i$ from light water to $\mathrm{NB}\left(\Delta G_{\mathrm{i}_{\mathrm{H}_{2} \mathrm{O}}}^{\theta^{\mathrm{NB}}}\right)$ and from heavy water to $\mathrm{NB}\left(\Delta G_{\mathrm{i}_{\mathrm{D}_{2} \mathrm{O}}}^{\theta^{\mathrm{NB}}}\right)$ represents the difference of the solvation energies of these ions in heavy and light water: $\Delta G_{\mathrm{i}_{\mathrm{H}_{2} \mathrm{O}}}^{\theta^{\mathrm{NB}}}-$ $\Delta G_{\mathrm{i}_{2} \mathrm{O}}^{\theta^{\mathrm{NB}}}=\Delta G_{\mathrm{i}_{\mathrm{H}_{2} \mathrm{O}}}^{\theta_{\mathrm{D}_{2} \mathrm{O}}}$. The values of $\Delta G_{\mathrm{i}_{\mathrm{H}_{2} \mathrm{O}}}^{\theta^{\mathrm{NB}}}$ and $\Delta G_{\mathrm{i}_{\mathrm{D}_{2} \mathrm{O}}}^{\theta^{\mathrm{NB}}{ }^{2} \mathrm{O}}$ for anions and cations can be determined from the formal potentials of the oxidation of dmfc (for anion transfer) and that of the reduction of $\mathrm{Fe}$ (III)TPP (for cation transfer) by applying three-phase electrodes $[7,16]$

$$
\begin{aligned}
& E_{\mathrm{f}}^{\theta^{\prime}}=E_{\left.\mathrm{dmfe}_{(\mathrm{o})}^{+}\right] \mathrm{dmfc}_{(\mathrm{o})}^{\theta}}^{\theta}+\frac{\Delta G_{\mathrm{A}^{-}{ }^{-} \mathrm{oq}}^{\theta}}{F}-\frac{R T}{F} \ln \left(c\left(\mathrm{~A}^{-}\right)_{(\mathrm{aq})}\right) \\
& +\frac{R T}{F} \ln \left(\frac{c^{*}(\mathrm{dmfc})_{(\mathrm{o})}}{2}\right),
\end{aligned}
$$

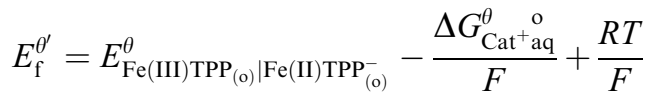

$$
\begin{aligned}
& \times \ln \left(c\left(\mathrm{Cat}^{+}\right)_{(\mathrm{aq})}\right)+\frac{R T}{F} \\
& \times \ln \left(\frac{2}{c^{*}(\mathrm{Fe}(\mathrm{III}) \mathrm{TPP})_{(\mathrm{o})}}\right) .
\end{aligned}
$$

In the Eqs. (1) and (2), $E_{\mathrm{f}}^{0^{\prime}}$ is the formal potential, $E_{\mathrm{dmfc}_{(0)}^{+} \mid \mathrm{dmfc}_{(0)}}^{\theta}$ and $E_{\mathrm{Fe}(\mathrm{III}) \mathrm{TPP}}^{\theta}\left(\mathrm{To}_{0}\right) \mathrm{Fe}_{(\mathrm{II}) \mathrm{TPP}_{(0)}^{-}}$are the standard redox potentials of $\mathrm{dmfc}_{\mathrm{dmfc}}{ }^{+}$and $\mathrm{Fe}(\mathrm{III}) \mathrm{TPP} /$ $\mathrm{Fe}(\mathrm{II}) \mathrm{TPP}^{-}$in the organic phase, respectively, while $\Delta G_{\mathrm{A}^{-}{ }^{\circ} \mathrm{aq}}$ and $\Delta G_{\mathrm{Cat}^{+}{ }^{\circ}{ }_{\mathrm{aq}}}$ are the standard Gibbs energies of transfer of anions and cations from the aqueous to the organic phase, respectively. $c\left(\mathrm{~A}^{-}\right)_{(\mathrm{aq})}$ and $c\left(\mathrm{Cat}^{+}\right)_{(\mathrm{aq})}$ are the concentrations of the transferable anions and cations in the aqueous phase, while $c^{*}(\mathrm{dmfc})_{(\mathrm{o})}$ and $c^{*}(\mathrm{Fe}(\mathrm{III}) \mathrm{TPP})_{(\mathrm{o})}$ are the initial concentrations of electroactive compounds $\mathrm{dmfc}$ and $\mathrm{Fe}(\mathrm{III}) \mathrm{TPP}$ in the organic phase, respectively. The meaning of $R, T$, and $F$ is as usual.

The determined values of standard Gibbs energies of transfer from light water to heavy water of various inorganic and organic cations and anions, together with some literature data, are given in Table 1. Obviously, the range of $\Delta G_{\mathrm{i}_{\mathrm{H}_{2} \mathrm{O}} \mathrm{O}}^{\mathrm{D}^{\mathrm{O}}}$ values is rather narrow, i.e., it varies between -0.50 and $+0.50 \mathrm{~kJ} / \mathrm{mol}$. From these $\Delta G_{\mathrm{i}_{\mathrm{H}_{2} \mathrm{O}}}^{\theta^{\mathrm{D}_{2} \mathrm{O}}}$ values one can estimate the ratio: solubility of $\mathrm{i}$ in $\mathrm{D}_{2} \mathrm{O} /$ solubility of i in $\mathrm{H}_{2} \mathrm{O}$. This ratio varies from 0.82 to 1.18 . The obtained values of the standard Gibbs energies of ion transfer from light to heavy water determined by our approach are not so much different from the values provided by other authors [4]. Table 1 also lists the contributions to the standard Gibbs energies of transfer that are due to the differences in dielectric constants 
Table 1

The formal potentials measured by square-wave voltammetry for the oxidation of dmfc and transfer of anions and reduction of Fe(III)TPP and transfer of cations, respectively, for the light water-nitrobenzene system $\left(E_{\mathrm{f}, \mathrm{i}_{\mathrm{H}_{2} \mathrm{O}}}^{\theta_{\mathrm{NB}}}\right)$ and the heavy water-nitrobenzene system $\left(E_{\mathrm{f}, \mathrm{i}_{2} \mathrm{O}}^{\theta^{\mathrm{NB}}}\right)$, the standard Gibbs energies of transfer of ions from light water to heavy water $\Delta G_{\mathrm{i}_{\mathrm{H}_{2} \mathrm{O}}}^{\mathrm{Q}^{\mathrm{D} \mathrm{O}}}$, the corresponding confidence intervals, and the literature data of standard Gibbs energies of ion transfer between light and heavy water

\begin{tabular}{|c|c|c|c|c|c|c|c|}
\hline Compound & 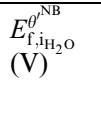 & 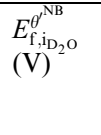 & 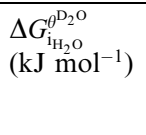 & $\begin{array}{l}\text { Confidence interval of } \\
\Delta G_{\mathrm{i}_{\mathrm{H}_{2} \mathrm{O}} \mathrm{O}}^{\mathrm{D}_{\mathrm{O}}}\left(\mathrm{kJ} \mathrm{mol}^{-1}\right) \\
(P=0.9)\end{array}$ & $\begin{array}{l}\text { Contribution from the } \\
\text { dielectric constants } \\
\Delta G_{\mathrm{i}_{\mathrm{H}_{2} \mathrm{O}}}^{\theta^{\mathrm{D}_{\mathrm{O}} \mathrm{O}}}\left(\mathrm{kJ} \mathrm{mol}^{-1}\right)\end{array}$ & $\begin{array}{l}\text { Contribution of } \\
\text { cavity formation } \\
\Delta G_{\mathrm{i}_{\mathrm{H}_{2} \mathrm{O}}}^{\theta^{\mathrm{D}} \mathrm{O}} \\
\left(\mathrm{kJ} \mathrm{mol}^{-1}\right)\end{array}$ & $\begin{array}{l}\text { Literature values of } \\
\Delta G_{\mathrm{i}_{\mathrm{H}_{2} \mathrm{O}}}^{\theta_{\mathrm{D}^{\mathrm{O}}}}\left(\mathrm{kJ} \mathrm{mol}^{-1}\right)\end{array}$ \\
\hline $\mathrm{BrO}_{3}^{-}$ & 0.044 & 0.041 & 0.29 & \pm 0.087 & 0.022 & & $1.14^{\mathrm{e}}$ \\
\hline $\mathrm{Cl}^{-}$ & 0.051 & 0.047 & 0.38 & \pm 0.083 & 0.023 & & $0.63^{\mathrm{d}} ; 0.45^{\mathrm{e}} ; 0.23^{\mathrm{e}}$ \\
\hline $\mathrm{OCN}^{-}$ & 0.010 & 0.010 & 0.00 & \pm 0.092 & 0.022 & & - \\
\hline $\mathrm{Br}^{-}$ & 0.005 & 0.001 & 0.38 & \pm 0.074 & 0.022 & & $0.71^{\mathrm{d}} ; 0.78^{\mathrm{e}} ; 0.31^{\mathrm{e}}$ \\
\hline $\mathrm{NO}_{3}^{-}$ & 0.046 & 0.042 & 0.38 & \pm 0.068 & 0.022 & & - \\
\hline $\mathrm{ClO}_{3}^{-}$ & 0.020 & 0.017 & 0.29 & \pm 0.070 & 0.021 & & - \\
\hline $\mathrm{I}^{-}$ & -0.034 & -0.038 & 0.38 & \pm 0.054 & 0.019 & & $0.91^{\mathrm{d}} ; 1.05^{\mathrm{e}} ; 0.52^{\mathrm{e}}$ \\
\hline $\mathrm{SCN}^{-}$ & -0.050 & -0.051 & 0.10 & \pm 0.058 & $0.021_{5}$ & & - \\
\hline $\mathrm{ClO}_{4}^{-}$ & -0.120 & -0.122 & 0.19 & \pm 0.077 & $0.017_{5}$ & & $0.37^{\mathrm{e}}$ \\
\hline Benzoate $^{-}$ & 0.086 & 0.086 & 0.00 & \pm 0.048 & & -0.365 & - \\
\hline Suprofen $^{-}$ & -0.029 & -0.031 & 0.19 & \pm 0.087 & & & - \\
\hline Warfarine $^{-}$ & -0.155 & -0.155 & 0.00 & \pm 0.061 & & & - \\
\hline Butyrate $^{-}$ & 0.049 & 0.047 & 0.19 & \pm 0.073 & & -0.270 & $-0.02^{\mathrm{d}}$ \\
\hline Acetate $^{-}$ & 0.069 & 0.068 & 0.10 & \pm 0.080 & & -0.080 & $0.03^{\mathrm{d}} ;-0.37^{\mathrm{e}}$ \\
\hline Picrate $^{-}$ & 0.015 & 0.019 & -0.38 & \pm 0.104 & & & - \\
\hline $\mathrm{THexN}^{+}$ & -0.096 & -0.102 & -0.50 & \pm 0.093 & 0.009 & -0.710 & - \\
\hline $\mathrm{TButN}^{+}$ & -0.164 & -0.165 & -0.10 & \pm 0.067 & 0.010 & -0.540 & $\begin{array}{l}-0.37^{\mathrm{d}} ;-0.31^{\mathrm{e}} \\
-0.95^{\mathrm{e}}\end{array}$ \\
\hline $\mathrm{Cs}^{+}$ & -0.268 & -0.266 & 0.19 & \pm 0.088 & 0.025 & & $0.41^{\mathrm{d}} ; 0.61^{\mathrm{e}} ; 0.48^{\mathrm{e}}$ \\
\hline $\mathrm{Rb}^{+}$ & -0.300 & -0.298 & 0.19 & \pm 0.117 & 0.028 & & $0.65^{\mathrm{d}} ; 0.46^{\mathrm{e}} ; 0.71^{\mathrm{e}}$ \\
\hline $\mathrm{K}^{+}$ & -0.354 & -0.348 & 0.50 & \pm 0.096 & 0.032 & & $0.44^{\mathrm{d}} ; 0.45^{\mathrm{e}} ; 0.50^{\mathrm{e}}$ \\
\hline
\end{tabular}

${ }^{\text {a }}$ The confidence interval of $\Delta G_{\mathrm{i}_{\mathrm{H}_{2} \mathrm{O}}}^{\mathrm{D}^{\mathrm{O}}}$ was estimated by using the equation: $\pm t(P, n) S / \sqrt{n}$, where $S$ was the standard deviation in the Gibbs energies of ion transfer and $n$ is the number of the measurements. The value of $t$ (for $n=10$, and probability of $P=0.9$ ) was 1.83 [20].

${ }^{\mathrm{b}}$ Estimated by using the Born electrostatic theory for ion transfer and $298 \mathrm{~K}$ [18].

${ }^{\mathrm{c}}$ Estimated as differences between the energies of making a hole in heavy water and light water, by using the values for surface tensions of light water and heavy water [21].

${ }^{\mathrm{d}}$ Data from [4] by using as a reference the standard Gibbs energy of transfer of $\mathrm{Na}^{+}$from light water to heavy water, estimated from the value for $\Delta H_{\mathrm{Na}_{\mathrm{H}_{2} \mathrm{O}}^{+}}^{\mathrm{D}^{\mathrm{O} \mathrm{O}}}$ of $2.55 \mathrm{~kJ} / \mathrm{mol}$ and the value of $T \Delta S_{\mathrm{Na}_{\mathrm{H}_{2} \mathrm{O}}^{+}}^{\mathrm{D}^{\mathrm{D}_{2} \mathrm{O}}}=2.38 \mathrm{~kJ} / \mathrm{mol}$.

${ }^{\mathrm{e}}$ Data from [22].

(according to simple Born theory [18]) and those that are due to the Gibbs energy of cavity formation (calculated from the differences in surface tension of light and heavy water). From the values of $\Delta G_{\mathrm{i}_{2} \mathrm{O}}^{\theta^{\mathrm{D}_{2} \mathrm{O}}}$ given in Table 1 one can conclude that most of the studied ions are stronger solvated in light water than in heavy water. The only exceptions are the picrate anion and the tetrabutylammonium $\left(\mathrm{TButN}^{+}\right)$and tetrahexylammonium $\left(\mathrm{THexN}^{+}\right)$ cations. Table 1 shows that the energies for cavity formation in light and heavy water differ rather strongly so that the transfer of large ions from light to heavy water should be favoured. However, especially for several organic ions (benzoate, suprofene, warfarine, butyrate and acetate), this effect seems to be overcompensated by another term, which might be an enthalpic or an entropic contribution. On the basis of the literature data and theory it seems not to be reasonable to decide what the compensating term is. Generally, it is obvious from Table 1 that the differences in dielectric constants $\left(\varepsilon_{\mathrm{H}_{2} \mathrm{O}}=78.40, \varepsilon_{\mathrm{D}_{2} \mathrm{O}}=78.03\right.$ at $\left.298 \mathrm{~K}\right)$ do not contribute more than $15 \%$ to the Gibbs energies of transfer. Some authors [19] ascribe the weaker solubility of various substances in heavy water as a result of the stronger selfassociation of heavy water molecules in comparison with light water.

\section{Conclusions}

The previously described approach to determine Gibbs energies of ion transfer with the help of threephase electrodes proved to be applicable to determine the small differences of ion transfer using light and heavy water on one side and nitrobenzene on the other. Although the confidence intervals are rather large, they allow making conclusions about the standard Gibbs energies of transfer of ions between light and heavy water. Thus, we have proved that these values are accessible for single ions by electrochemical measurements. At present it seems that due to several inconsistencies between the data reported and reviewed in the literature [22] it is not possible to judge about the correctness of one or the other values. However, it is clear from Table 1 that our values and those reported 
earlier are of the same order of magnitude and rather similar. We believe that the present study will encourage further studies that may lead to reliable data sets and a clear understanding of the isotope effect on the solvation of ions.

\section{Acknowledgements}

F.S. acknowledges support by Deutsche Forschungemeinschaft (DFG) and Fonds der Chemischen Industrie (FCI), R.G. thanks Deutscher Akademischer Austauschdienst (DAAD) for provision of a Ph.D. scholarship, K.C. thanks DAAD for support.

\section{References}

[1] L.P. Hammett, Physikalische Organische Chemie, AkademieVerlag, Berlin, 1976.

[2] A.E. Brodsky, Isotopenchemie, Akademie-Verlag, Berlin, 1961.

[3] S.J. Wilkins, A. Coles, R.G. Compton, Chem. Commun. (2002) 698.

[4] G. Jancso, A. van Hook, Chem. Rev. 74 (1974) 690.

[5] V. Mareček, J. Heyrovský Institute, Prague, private communication.

[6] H.H. Girault, D.J. Schiffrin, Electrochemistry of liquid-liquid interfaces, in: A.J. Bard (Ed.), Electroanalytical Chemistry, A Series of Advances, vol. 15, Marcel Dekker, New York, 1989.
[7] F. Scholz, Š. Komorsky-Lovrić, M. Lovrić, Electrochem. Commun. 2 (2000) 112.

[8] R. Gulaboski, V. Mirčeski, F. Scholz, Electrochem. Commun. 4 (2002) 277.

[9] V. Mirčeski, R. Gulaboski, F. Scholz, Electrochem. Commun. 4 (2002) 813.

[10] R. Gulaboski, K. Riedl, F. Scholz, Phys. Chem. Chem. Phys. 5 (2003) 1284.

[11] Š. Komorsky-Lovrić, K. Riedl, R. Gulaboski, V. Mirčeski, F. Scholz, Langmuir 18 (2002) 8000; Langmuir 19 (2003) 3090.

[12] R. Gulaboski, F. Scholz, J. Phys. Chem. B 107 (2003) 5650

[13] R. Gulaboski, V. Mirčeski, F. Scholz, Amino Acids 24 (2003) 149.

[14] F. Scholz, R. Gulaboski, V. Mirčeski, P. Langer, Electrochem. Commun. 4 (2002) 659.

[15] G. Bouchard, A. Galland, P.-A. Carrupt, R. Gulaboski, V. Mirčeski, F. Scholz, H.H. Girault, Phys. Chem. Chem. Phys. 5 (2003) 3748-3751.

[16] F. Scholz, R. Gulaboski, K. Caban, Electrochem. Commun. 5 (2003) 929-934.

[17] M. Lovrić, in: F. Scholz (Ed.), Electroanalytical Methods: Guide to Experiments and Applications, Springer, Berlin Heidelberg, 2002, pp. 111-133.

[18] A.G. Volkov, Liquid-liquid Interfaces in Chemical, Biological, and Pharmaceutical Applications, Marcel Dekker, New York, 2001.

[19] M. Jelinska-Kazimierczuk, J. Szydlowski, J. Solution Chem. 25 (1996) 1175.

[20] K. Doerffel, Statistik in der Analytischen Chemie, VEB Deutscher Verlag für Grundstoffindustrie, Leipzig, 1982.

[21] J. Bukovsky, K. Haack, Heavy Water Handbook, Risö National Laboratory, Roskilde, 1994.

[22] Y. Marcus, Ion Properties, Marcel Dekker, New York, 1997. 